\title{
PENGEMBANGAN MODUL PEMBELAJARAN KIMIA BERBASIS PENDEKATAN SAINTIFIK UNTUK SISWA SMA
}

\section{DEVELOPMENT OF CHEMISTRY LEARNING MODULES WITH SCIENTIFIC APPROACH BASED FOR SENIOR HIGH SCHOOL STUDENT}

\author{
Raden Apriadi ${ }^{1 *}$, Yayuk Andayani ${ }^{2}$, dan Muntari ${ }^{2}$ \\ ${ }^{1}$ Magister Pendidikan IPA, Program Pascasarjana Universitas Mataram, Mataram, Indonesia \\ ${ }^{2}$ Program Studi Pendidikan Kimia FKIP Universitas Mataram, Mataram, Indonesia \\ *Email:radenapriadi87@gmail.com
}

Diterima: 20 Juli 2018. Disetujui: 25 September 2018. Dipublikasikan: 30 September 2018

\begin{abstract}
Abstrak: Penelitian ini bertujuan untuk mengembangkan modul pembelajaran kimia berbasis pendekatan saintifik yang layak digunakan dalam proses pembelajaran di dalam kelas. Modul pembelajaran kimia dikembangkan pada materi pokok asam dan basa. Metode penelitian yang digunakan adalah research and develovement $(R \& D)$. Model pengembangannya menggunakan model Borg and Gall yang dimodifikasi dengan model Dick and Carrey. Tahapan pengembangan modul pembelajaran kimia terdiri dari: analisis kebutuhan, analisis pembelajaran, karakteristik siswa, dan perumusan tujuan (indikator hasil belajar), kemudian dilanjutkan dengan pengembangan produk awal (desain produk), validasi desain, perbaikan desain (revisi), dan uji coba produk. Uji coba dimaksudkan untuk mengetahui kelayakan modul secara empiris, uji coba dilaksanakan di dua sekolah dengan menggunakan dua kelas pada masing-masing sekolah, yaitu kelas XI IPA 1 dan XI IPA 2 SMA Negeri 1 Bayan dan XI IPA 1 dan XI IPA 3 SMA Negeri 1 Gangga. Hasil uji coba modul pembelajaran kimia selanjutnya dianalisis menggunakan rumus rata-rata dan disesuaikan dengan tabel kriteria validasi. Kesimpulan hasil penelitian ini yaitu modul pembelajaran kimia berbasis pendekatan saintifik yang dikembangkan dikategorikan baik dan layak digunakan dalam proses pembelajaran di dalam kelas.
\end{abstract}

Kata Kunci: Modul pembelajaran kimia, Pendekatan Saintifik.

\begin{abstract}
This study aims to develop Chemistry learning modules based on scientific approach which is suitable to apply on learning process in the classroom. This module is developed in the main subject of Acids and Bases. The method used in this study is research and develovement ( $R$ \& D). The development model modified from Borg and Gall with Dick and Carrey models. The stages of chemistry learning module development consists of: requirement analysis, analysis of learning, student characteristics, and the formulation of objectives (indicators of learning outcomes), then proceed with the early product development (product design), design validation, design improvements (revised), and product trials. The trial is intended to determine the feasibility of the modules empirically, a trial was conducted in two schools by using two classes at each school, the class XI IPA 1 and XI IPA 2 SMA Negeri 1 Bayan and XI IPA 1 and XI IPA 3 SMAN 1 Ganga. The trial result of chemistry learning modules then analyzed using the average formula and adapted to the table of validation criteria. The conclusion, the results of this study are chemistry learning modules with scientific approaches are categorized as good and suitable for use in the learning process in the classroom.
\end{abstract}

Keywords: Chemistry learning modules, The Scientific Approach.

\section{PENDAHULUAN}

Hasil studi pendahuluan (observasi) yang dilakukan oleh peneliti pada bulan September 2014 di SMA Negeri 1 Bayan dan SMA Negeri 1 Gangga, diketahui bahwa proses pembelajaran masih berpusat pada guru artinya aktivitas guru didalam kelas lebih banyak dibandingkan dengan siswanya, tanpa disadari hal semacam ini memberikan dampak yang kurang baik dalam proses pembelajaran. Guru menuntut siswa untuk mampu menghafal materi, baik yang disampaikan oleh guru maupun dari buku ajar, tanpa melakukan refleksi kritis atas pengalaman belajarnya sebagai bekal dimasa mendatang, sehingga proses pembelajaran di dalam kelas tidak bisa berjalan dengan maksimal. Tentu ini bertolak belakang dari tuntutan kurikulum 2013, yang mengedepankan keterampilan proses dan dititik beratkan pada dua kompetensi yaitu kompetensi berpikir dan kompetensi komunikasi. [1] melaporkan bahwa, kompetensi berpikir merupakan kompetensi sumber daya manusia yang memiliki pengetahuan luas, memiliki kemampuan berpikir kritis, dan memiliki kemampuan berpikir kreatif. Sedangkan kompetensi komunikasi merupakan kompetensi sumber daya manusia yang hendaknya memiliki kemampuan berkomunikasi dalam rangka bekerja sama dan menyampaikan ide-ide kritis kreatifnya.

Kondisi di atas tidak sesuai dengan tujuan pembelajaran IPA khususnya kimia, karena pembelajaran tidak hanya fokus pada memahami pengetahuan tetapi juga memberikan kesempatan 
pada siswa agar mampu terlibat secara langsung dalam belajar dengan menggunakan pendekatan ilmiah yang dimiliki. Guru berupaya semaksimal mungkin memberikan pengalaman dan memperkaya pengetahuan siswa dengan mengeksplorasi lingkungan sekitar melalui proses pembelajaran, sehingga peran guru sebagai fasilitator dan motivator dapat terlaksana.

Menurut no [9], peran guru sebagai fasilitator adalah memberikan fasilitas atau kemudahan dalam proses belajar-mengajar, misalnya dengan menciptakan suasana kegiatan belajar yang sedemikian rupa, serasi dengan perkembangan siswa, sehingga interaksi belajarmengajar akan berlangsung secara efektif. Begitu pula halnya ketika guru bertindak sebagai motivator, guru harus dapat merangsang dan memberikan dorongan untuk mendinamisasikan potensi siswa, menumbuhkan swadaya (aktivitas) dan daya cipta (kreativitas), sehingga akan terjadi dinamika didalam proses belajar-mengajar. Namun hal itu terkadang dilupakan oleh guru sehingga dalam proses pembelajaran di kelas, aktivitas guru lebih dominan dibandingkan siswanya, dan tanpa disadari tindakan seperti itu akan mematikan kreatifitas siswa dalam berfikir dan mengembangkan kemampuan yang ada dalam diri siswa itu sendiri.

Hasil wawancara peneliti dengan guru kimia kelas XI IPA SMA Negeri 1 Bayan dan SMA Negeri 1 Gangga, diketahui bahwa guru kimia masih merasa kesulitan dalam menerapkan dan mengarahkan siswa untuk belajar menggunakan pendekatan saintifik, sehingga untuk mempermudah guru dalam menyampaikan materi kimia di dalam kelas, guru menggunakan teknik ceramah. Terlebih lagi buku ajar yang digunakan oleh siswa yang diberikan oleh pemerintah saat ini masih bersifat umum yaitu hanya berisi uraian materi tanpa ada variasi yang menarik dari buku sehingga terkadang membuat siswa jenuh dan bosan untuk membacanya.

Melihat permasalahan tersebut melalui penelitian ini akan dikembangkan sebuah modul pembelajaran kimia berbasis pendekatan saintifik pada materi pokok Asam Basa. Modul pembelajaran kimia yang dikembangkan disesuaikan dengan karakter siswa sehingga bentuk modul lebih spesifik dari buku ajar biasa, dengan demikian diharapkan pembelajaran akan lebih hidup dan terarah karena mampu membangun kerjasama antara siswa dengan siswa dan antara siswa dengan guru. Seperti yang diungkapkan oleh [8] bahwa, pengajaran modul dapat mengurangi atau menghilangkan sedapat mungkin rasa persaingan dikalangan siswa karena semua dapat mencapai hasil tertinggi sehingga dengan sendirinya lebih terbuka jalan ke arah kerjasama, baik antara murid dengan guru karena kedua belah pihak merasa bertanggung jawab atas berhasilnya pengajaran.

Modul dalam hal ini merupakan sebuah bahan ajar yang disusun secara sistematis dengan menggunakan bahasa yang mudah dipahami oleh siswa sesuai dengan tingkat pengetahuan dan usianya agar mereka dapat belajar sendiri (mandiri) dengan bantuan atau bimbingan yang minimal dari guru. [3] mengungkapkan, beberapa hasil penelitian menunjukkan bahwa modul yang digunakan belajar secara mandiri dapat membantu memudahkan pemahaman konsep serta memberikan dampak positif terhadap hasil belajar siswa.

Berdasarkan pemaparan diatas, maka rumusan masalah yang menjadi fokus kajian dalam penelitian ini adalah: (1) bagaimana mengembangkan modul pembelajaran kimia berbasis pendekatan saintifik pada materi pokok asam dan basa, (2) bagaimana kelayakan modul pembelajaran kimia berbasis pendekatan saintifik pada materi pokok asam dan basa.

Berdasarkan rumusan masalah tersebut, maka tujuan dari penelitian ini adalah tersusunnya modul pembelajaran kimia berbasis pendekatan saintifik yang layak digunakan dalam proses pembelajaran didalam kelas.

\section{METODE PENELITIAN}

Penelitian ini merupakan penelitian pengembangan. Jenis penelitian ini tidak dimaksudkan untuk menguji teori akan tetapi pengembangan yang dimaksudkan untuk menghasilkan suatu produk.

Model pengembangan dalam penelitian ini mengikuti model pengembangan Borg and Gaal yang dimodifikasi dengan model pengembangan Dick and Carrey. Model pengembangan Dick and Carrey terdiri atas sepuluh tahapan, dan dalam penelitian ini hanya diambil empat tahapan yaitu tahap analisis kebutuhan, analisis pembelajaran, karakteristik siswa, dan perumusan tujuan (indikator hasil belajar), kemudian dilanjutkan dengan model pengembangan Borg and Gall yang terdiri atas sepuluh tahapan juga, akan tetapi dalam penelitian ini hanya diambil empat tahapan yaitu tahap mengembangkan produk awal (desain produk), validasi desain, perbaikan desain (revisi), dan uji coba produk. Teknik pengambilan data dalam penelitian ini menggunakan lembar validasi ahli, angket respon siswa dan guru yang belajar menggunakan modul.

Uji coba produk skala terbatas dilaksanakan di dua sekolah dengan menggunakan dua kelas pada masing-masing sekolah yaitu kelas XI IPA 1 dan XI IPA 2 di SMA Negeri 1 Bayan dan kelas XI IPA 1 serta XI IPA 3 di SMA Negeri 1 Gangga, satu kelas belajar menggunakan modul kimia berbasis pendekatan saintifik dan satu kelas lainnya belajar tanpa menggunakan modul kimia 
berbasis pendekatan saintifik (buku kimia Kurikulum 2013 yang diberikan oleh sekolah).

Hasil validasi ahli dan hasil uji coba produk berupa modul pembelajaran kimia berbasis pendekatan saintifik diketahui layak atau tidaknya, dihitung menggunakan rumus Sudjana dalam [4].

$$
\bar{X}=\frac{\sum X}{n}
$$

Tabel 1 kriteria nilai rerata skor masing-masing komponen [11]

\begin{tabular}{ccl}
\hline Nilai & Interval Skor & \multicolumn{1}{c}{ Kategori } \\
\hline A & $4,21-5,00$ & Sangat Baik \\
B & $3,41-4,20$ & Baik \\
C & $2,61-3,40$ & Cukup \\
D & $1,81-2,60$ & Kurang \\
E & $1,00-1,80$ & Sangat Kurang \\
\hline
\end{tabular}

\section{HASIL DAN PEMBAHASAN}

Hasil penelitian ditunjukkan oleh data sebagai berikut:

Tabel 2 Hasil uji kelayakan modul menurut guru, dan siswa

\begin{tabular}{|c|c|c|c|c|c|}
\hline No & Aspek & $\mathrm{G}$ & $\mathrm{S}$ & Rt-rt & Kriteria \\
\hline 1 & $\begin{array}{l}\text { Wujud fisik } \\
\text { modul }\end{array}$ & 4,38 & 4,17 & 4,28 & SB \\
\hline 2 & Isi modul & 4,65 & 3,98 & 4,32 & SB \\
\hline 3 & $\begin{array}{l}\text { Respon/pen } \\
\text { erimaan }\end{array}$ & 4,56 & 4,16 & 4,36 & SB \\
\hline \multicolumn{6}{|c|}{ Keteranga: } \\
\hline G & : Guru & \multirow{2}{*}{\multicolumn{2}{|c|}{$\begin{array}{l}\text { SB } \\
\mathrm{Rt}\end{array}$}} & \multicolumn{2}{|c|}{ : Sangat Baik } \\
\hline$S$ & $\begin{array}{l}\text { : Siswa } \\
\text {. Baik }\end{array}$ & & & \multicolumn{2}{|c|}{ Rata-rata } \\
\hline
\end{tabular}

Tabel 3 Hasil rata-rata validasi ahli terhadap modul

\begin{tabular}{cccl}
\hline No & Penilaian & Rata-rata & \multicolumn{1}{c}{ Kriteria } \\
\hline 1. & Validator 1 & 4,30 & Sangat Baik \\
2. & Validator 2 & 4,40 & Sangat Baik \\
3. & Validator 3 & 3,12 & Cukup \\
& Rata-Rata & 3,94 & Baik \\
\hline
\end{tabular}

Tabel 4 Hasil respon guru kimia SMAN Bayan dan SMAN 1 Gangga terhadap modul

\begin{tabular}{|c|c|c|c|c|c|}
\hline \multirow[b]{2}{*}{ No } & \multirow{2}{*}{$\begin{array}{c}\text { Nama } \\
\text { Sekolah }\end{array}$} & \multicolumn{2}{|c|}{ Penilaian } & \multirow[b]{2}{*}{$\begin{array}{l}\text { Rata- } \\
\text { Rata }\end{array}$} & \multirow[b]{2}{*}{ Kriteria } \\
\hline & & $\begin{array}{c}\text { Guru } \\
\text { I }\end{array}$ & $\begin{array}{c}\text { Guru } \\
\text { II }\end{array}$ & & \\
\hline 1 & $\begin{array}{l}\text { SMAN } \\
\text { Bayan }\end{array}$ & 4,60 & 4,33 & 4,47 & $\begin{array}{l}\text { Sangat } \\
\text { Baik }\end{array}$ \\
\hline 2 & $\begin{array}{l}\text { SMAN } 1 \\
\text { Gangga }\end{array}$ & 4,33 & 4,80 & 4,57 & $\begin{array}{l}\text { Sangat } \\
\text { Baik }\end{array}$ \\
\hline
\end{tabular}

Tabel 5 Hasil respon siswa SMAN 1 Bayan dan SMAN 1 Gangga terhadap modul

\begin{tabular}{ccl}
\hline Deskriptor & Rata-rata & \multicolumn{1}{c}{ Kriteria } \\
\hline 1 & 4.00 & Baik \\
2 & 3.94 & Baik \\
3 & 3.94 & Baik \\
4 & 3.96 & Baik \\
5 & 4.39 & Sangat Baik \\
6 & 4.33 & Sangat Baik \\
7 & 4.04 & Baik \\
8 & 4.53 & Sangat Baik \\
9 & 4.26 & Sangat Baik \\
10 & 4.02 & Baik \\
11 & 3.76 & Baik \\
12 & 4.41 & Sangat Baik \\
Rata-rata & 4,13 & Baik \\
\hline
\end{tabular}

Keterangan:

1. Uraian materi dalam modul jelas dan mudah dipahami.

2. Simbol-simbol yang digunakan dalam modul sangat jelas.

3. Soal latihan yang diberikan sesuai dengan materi yang dijabarkan dalam modul.

4. Kalimat yang digunakan dalam modul tidak menimbulkan makna ganda.

5. Bahasa yang digunakan dalam modul mudah untuk saya pahami

6. Modul yang digunakan menumbuhkan rasa ingin tahu saya.

7. Modul yang digunakan membuat saya aktif dalam mengikuti pembelajaran.

8. Modul yang digunakan membantu saya dalam memahami materi asam basa.

9. Modul yang digunakan menyenangkan dalam pembelajaran.

10. Modul yang digunakan dapat memberikan saya pengalaman belajar yang berarti.

11. Modul yang digunakan memudahkan saya memecahkan permasalahan dalam pembelajaran.

12. Penampilan modul dapat mendorong minat baca saya.

Tabel 6. Hasil uji kelayakan buku kimia Kurikulum 2013 pokok bahasan asam basa menurut guru dan siswa

\begin{tabular}{cccccc}
\hline No & Aspek & Guru & Siswa & $\begin{array}{c}\text { Rata- } \\
\text { rata }\end{array}$ & Kriteria \\
\hline 1 & $\begin{array}{l}\text { Wujud } \\
\text { fisik } \\
\text { buku }\end{array}$ & 3,46 & 2,57 & 3,02 & Cukup \\
2 & $\begin{array}{l}\text { Isi buku } \\
\text { Respon/ } \\
\text { penerim } \\
\text { aan }\end{array}$ & 2,35 & 3,03 & 3,19 & Cukup \\
3 & 2,47 & 2,71 & Cukup \\
\hline
\end{tabular}


Tabel 7. Hasil respon guru kimia SMAN 1 Bayan dan SMAN 1 Gangga terhadap buku kimia Kurikulum 2013 pokok bahasan asam basa

\begin{tabular}{|c|c|c|c|c|c|}
\hline \multirow[b]{2}{*}{ No } & \multirow{2}{*}{$\begin{array}{c}\text { Nama } \\
\text { Sekolah }\end{array}$} & \multicolumn{2}{|c|}{ Penilaian } & \multirow{2}{*}{$\begin{array}{l}\text { Rata- } \\
\text { Rata }\end{array}$} & \multirow[b]{2}{*}{ Kriteria } \\
\hline & & $\begin{array}{c}\text { Guru } \\
\text { I }\end{array}$ & $\begin{array}{c}\text { Guru } \\
\text { II }\end{array}$ & & \\
\hline 1 & $\begin{array}{c}\text { SMAN } 1 \\
\text { Bayan }\end{array}$ & 3,20 & 3,40 & 3,30 & Cukup \\
\hline 2 & $\begin{array}{c}\text { SMAN } 1 \\
\text { Gangga }\end{array}$ & 3,20 & 3,33 & 3,27 & Cukup \\
\hline
\end{tabular}

Tabel 8 Hasil respon siswa SMAN 1 Bayan dan SMAN 1 Gangga terhadap buku kimia Kurikulum 2013 pokok bahasan asam basa

\begin{tabular}{ccl}
\hline Deskriptor & Rata-rata & \multicolumn{1}{c}{ Kriteria } \\
\hline 1 & 3.07 & Cukup \\
2 & 2.96 & Cukup \\
3 & 3.00 & Cukup \\
4 & 2.85 & Cukup \\
5 & 2.35 & Kurang \\
6 & 2.17 & Kurang \\
7 & 2.33 & Kurang \\
8 & 2.76 & Cukup \\
9 & 2.20 & Kurang \\
10 & 2.48 & Cukup \\
11 & 2.87 & Cukup \\
12 & 2.13 & Kurang \\
Rata-rata & 2.60 & Kurang \\
\hline
\end{tabular}

Keterangan:

1. Uraian materi dalam buku kimia Kurikulum 2013 pokok bahassan asam basa jelas dan mudah dipahami.

2. Simbol-simbol yang digunakan dalam buku kimia Kurikulum 2013 pokok bahasan asam basa sangat jelas.

3. Soal latihan yang diberikan sesuai dengan materi yang dijabarkan dalam buku kimia Kurikulum 2013 pokok bahasan asam basa.

4. Kalimat yang digunakan dalam buku kimia Kurikulum 2013 pokok bahasan asam basa tidak menimbulkan makna ganda.

5. Bahasa yang digunakan dalam buku kimia Kurikulum 2013 pokok bahasan asam basa mudah untuk saya pahami

6. Buku kimia Kurikulum 2013 pokok bahasan asam basa yang digunakan menumbuhkan rasa ingin tahu saya.

7. Buku kimia Kurikulum 2013 pokok bahasan asam basa yang digunakan membuat saya aktif dalam mengikuti pembelajaran.

8. Buku kimia Kurikulum 2013 pokok bahasan asam basa yang digunakan membantu saya dalam memahami materi asam basa.

9. Buku kimia Kurikulum 2013 pokok bahasan asam basa yang digunakan menyenangkan dalam pembelajaran.
10. Buku kimia Kurikulum 2013 pokok bahasan asam basa yang digunakan dapat memberikan saya pengalaman belajar yang berarti.

11. Buku kimia Kurikulum 2013 pokok bahasan asam basa yang digunakan memudahkan saya memecahkan permasalahan dalam pembelajaran.

12. Penampilan Buku kimia Kurikulum 2013 pokok bahasan asam basa dapat mendorong minat baca saya

Merujuk pada hasil uji kelayakan terhadap tiga aspek dari modul yaitu wujud fisik modul, isi modul, dan respon/penerimaan terhadap modul, menurut penilaian ahli, guru, dan siswa diketahui bahwa, modul pembelajaran kimia berbasis pendekatan saintifik yang dikembangkan memiliki keunggulan terhadap respon/penerimaan, hal ini terlihat dari nilai rata-rata yang diberikan sebesar 4,22 dengan kriteria sangat baik, dengan demikian modul pembelajaran kimia yang dikembangkan diterima dan sangat membantu dalam proses pembelajaran. Pernyataan ini sejalan dengan hasil penelitian [2] bahwa, belajar menggunakan modul memberikan respon positif, pembelajaran menjadi menyenangkan, menarik, mudah dipahami, dan mendorong siswa belajar secara aktif yaitu aktif berpikir dan aktif melaksanakan. Jika dibandingkan dengan hasil uji kelayakan terhadap buku kimia Kurikulum 2013 pokok bahasan asam basa, modul pembelajaran kimia berbasis pendekatan saintifik lebih unggul, baik dari aspek wujud fisik, isi, ataupun respon/penerimaan.

Jika dilihat nilai validasi yang diberikan oleh validator terhadap modul pembelajaran kimia berbasis pendekatan saintifik yang telah dikembangkan, diperoleh nilai dari validator satu dengan kategori sangat baik $(4,30)$, validator dua sangat baik $(4,40)$, dan validator tiga cukup $(3,12)$. Total penilaian semua validator dengan kategori baik $(3,94)$, artinya modul pembelajaran kimia berbasis pendekatan saintifik layak secara teori dan siap untuk diuji coba dalam skala terbatas.

Uji coba terbatas dimaksudkan untuk melihat kelayakan modul pembelajaran kimia yang dikembangkan secara empiris, uji coba ini dilaksanakan dengan desain satu kelas belajar menggunakan modul dan satu kelas belajar menggunakan buku kimia Kurikulum 2013 pokok bahasan asam basa. Beberapa perbedaan antara modul yang dikembangkan dengan buku kimia Kurikulum 2013 pokok bahasan asam basa adalah pada modul terdapat petunjuk penggunaan modul, tahapan pendekatan saintifik pada setiap bahasan materi, kunci jawaban dari soal latihan perkegiatan belajar, dan umpan balik diakhir kegiatan belajar yang dimaksudkan agar siswa dapat mengetahui tingkat penguasaan konsep terhadap materi yang dipelajari, sedangkan pada buku kimia Kurikulum 2013 pokok bahasan asam basa, tidak terdapat 
petunjuk penggunaan buku, tahapan pendekatan saintifik, kunci jawaban dari soal latihan, dan umpan balik diakhir kegiatan belajar.

Adanya petunjuk penggunaan dalam modul yang dikembangkan akan memudahkan siswa untuk belajar secara mandiri, seperti yang diungkapkan oleh [13], bahwa modul merupakan bahan ajar berbasis cetakan yang dirancang untuk belajar secara mandiri, karena itu modul dilengkapi dengan petunjuk untuk belajar sendiri. Tahapan pendekatan saintifik digunakan dalam modul karena mampu membangun pengetahuan dengan mengembangkan kemampuan berpikir kreatif siwa, sesuai dengan pernyataan [7] bahwa, pembelajaran dengan pendekatan saintifik yang mengadopsi langkah-langkah saintis dapat membangun pengetahuan dan kecakapan berpikir sains serta kemampuan berpikir kreatif siswa. Adanya kunci jawaban dari soal latihan memberikan kemudahan pada siswa untuk mengetahui kebenaran jawabannya. Pernyataan ini sesuai dengan ungkapan [2] bahwa, kunci jawaban perlu diberikan pada siswa sebagai pedoman atau acuan untuk mengetahui kebenaran jawaban yang telah dibuat oleh siswa. Tidak hanya itu, umpan balik diakhir kegiatan belajarpun perlu diberikan, dimaksudkan agar siswa dapat mengetahui tingkat penguasaan konsep terhadap materi yang dipelajari di dalam modul. Sebagaimana yang diungkapkan oleh [2] bahwa, umpan balik bertujuan untuk memberi kesempatan pada siswa untuk memeriksa pemahamannya atau mengetahui sampai dimana materi modul dikuasai, sehingga siswa dapat memperbaiki kekurangannya, selain itu, didalam modul yang dikembangkan, dilengkapi juga dengan glosarium, ini dimaksudkan untuk menambah wawasan bagi siswa serta mengulas konsep-konsep yang telah dipelajari oleh siswa [5].

Adanya tahapan pendekatan saintifik pada modul memberikan kemudahan kepada guru dalam melaksanakan proses pembelajaran sesuai Kurikulum 2013, hal ini terlihat dari respon guru yang belajar menggunakan modul, dari hasil analisis angket diketahui rata-rata penilaian guru di SMA Negeri 1 Bayan sebesar 4,47 dengan kategori sangat baik, demikian pula halnya dengan penilaian guru di SMA Negeri 1 Gangga, hasil analisis angket diperoleh rata-rata sebesar 4,57 dengan kategori sangat baik. Tanggapan guru yang memberikan nilai positif, didukung juga oleh tanggapan siswa yang belajar menggunakan modul, hasil analisis angket siswa yang belajar menggunakan modul diketahui rata-rata sebesar 4,13 dengan kategori baik. Nilai ini menunjukkan bahwa modul pembelajaran kimia berbasis pendekatan saintifik yang dikembangkan layak digunakan dan membantu dalam proses pembelajaran.

Berbeda halnya dengan penilaian guru dan siswa yang belajar menggunakan buku kimia
Kurikulum 2013 pokok bahasan asam basa, dari hasil analisis angket oleh guru, diketahui rata-rata penilaian guru di SMA Negeri 1 Bayan sebesar 3,30, dan SMA Negeri 1 Gangga sebesar 3,27. Ke dua penilaian tersebut masuk dalam kategori cukup. Nilai ini menunjukkan bahwa buku kimia Kurikulum 2013 pokok bahasan asam basa cukup membantu dalam proses pembelajaran. Hasil yang berbeda diberikan oleh siswa, dimana hasil analisis angket respon siswa diketahui rata-rata penilaian siswa sebesar 2,60 dengan kategori kurang, artinya siswa masih merasa kesulitan pada saat belajar menggunakan buku kimia Kurikulum 2013 pokok asam basa.

Jika dilihat dari hasil penilaian antara belajar menggunakan modul dan buku kimia Kurikulum 2013 pokok bahasan asam basa, terdapat perbedaan yang jelas. Perbedaan hasil ini merupakan indikator bahwa modul pembelajaran kimia berbasis pendekatan saintifik yang dikembangkan lebih mampu mengoptimalkan keaktifan siswa dalam proses pembelajaran di kelas. Pernyataan ini sesuai dengan ungkapan [10], bahwa belajar menggunakan modul dapat mengaktifkan siswa dan mengurangi kebergantungan terhadap guru, sehingga peran guru dalam hal ini hanya sebagai fasilitator. Tidak hanya data respon yang berbeda, hasil evaluasi yang diberikan ke siswapun memperoleh nilai berbeda, dimana hasil evaluasi sebagian besar siswa yang belajar menggunakan modul lebih baik dibandingkan dengan hasil siswa yang belajar menggunakan buku kimia Kurikulum 2013 pokok bahasan asam basa, hal ini sejalan dengan pernyataan [3], bahwa belajar secara mandiri menggunakan modul dapat memudahkan pemahaman konsep dan memberikan dampak positif terhadap hasil belajar. Senada dengan pernyataan tersebut, [12], mengungkapkan bahwa pembelajaran menggunakan modul diyakini dapat mengubah konsepsi siswa menuju konsep ilmiah, yang akhirnya dapat meningkatkan hasil belajar seoptimal mungkin.

Hasil pengamatan peniliti pada saat uji coba modul kimia, yang dilaksanakan selama lima kegiatan belajar, diketahui bahwa modul pembelajaran kimia berbasis pendekatan saintifik secara umum memberikan dampak positif, terlihat dari keaktifan siswa pada saat belajar didalam kelas, dan respon siswa yang diberikan setelah belajar menggunakan modul, serta hasil belajar yang dicapai yaitu rata-rata diatas KKM. Dampak positif yang diberikan disebabkan karena siswa tidak merasa kesulitan ketika belajar menggunakan modul, sehingga memudahkan siswa untuk belajar kapanpun waktu yang diinginkan, hal ini sejalan dengan tujuan pembelajaran menggunakan modul menurut [12], bahwa belajar menggunakan modul menyediakan waktu sebanyak yang diperlukan oleh siswa dalam batas-batas yang dimungkinkan untuk menyelenggarakan pendidikan yang teratur. 
Pembelajaran menggunakan modul pada dasarnya melatih siswa untuk belajar mandiri karena modul tidak hanya dapat dipelajari di kelas tetapi dapat juga dipelajari diluar kelas, sehingga siswa dapat menguji kemampuannya sendiri dengan mengerjakan latihan soal yang terdapat pada modul serta melakukan umpan balik terhadap hasilnya sendiri. Pernyataan ini sesuai yang diungkapkan oleh [6], bahwa belajar menggunakan modul memiliki beberapa manfaat yaitu: (a) siswa memiliki kesempatan melatih diri belajar secara mandiri, (b) belajar menjadi lebih menarik karena dapat dipelajari diluar kelas dan diluar jam pembelajaran, (c) berkesempatan menguji kemampuan diri sendiri dengan mengerjakan latihan soal yang terdapat pada modul, dan (d) berkesempatan mengekspresikan cara-cara belajar yang sesuai dengan kemampuannya.

Berbeda halnya dengan pembelajaran menggunakan buku kimia Kurikulum 2013 pokok bahasan asam basa, hasil pengamatan peneliti pada saat penggunaan buku kimia pokok bahasan asam basa yang dilaksanakan selama lima kali pertemuan, diketahui bahwa hasil belajar siswa yang dicapai rata-rata dibawah KKM.

\section{KESIMPULAN}

Berdasarkan hasil dan pembahasan di atas dapat disimpulkan bahwa: 1) Modul pembelajaran kimia berbasis pendekatan saintifik pada pokok bahasan asam dan basa dikembangkan menggunakan model pengembangan Borg and Gall dan dimodifikasi dengan model Dick and Carrey dengan tahapan: (a) analisis kebutuhan; (b) analisis pembelajaran; (c) analisis karakteristik siswa; (d) perumusan tujuan/indikator hasil belajar; (e) mengembangkan produk awal (desain produk) dengan langkah: identifikasi masalah, penetapan judul modul, penyiapan buku-buku sumber/refrensi, identifikasi pencapaian kompetensi, dan penyusunan draft awal modul; (f) validasi desain; (g) perbaikan desain (revisi); dan (h) uji coba produk. 2) Modul pembelajaran kimia berbasis pendekatan saintifik pada pokok bahasan asam dan basa layak digunakan dalam proses pembelajaran.

\section{DAFTAR PUSTAKA}

[1] Abidin, Yunus. 2014. Desain Sistem Pembelajaran dalam Konteks Kurikulum 2013. Bandung: PT Refika Aditama.

[2] Suci, M. A. (2016). Pengembangan modul biologi berorientasi siklus belajar pada materi sistem reproduksi manusia untuk siswa kelas XI MIA di SMA Negeri 1 Tumpang (Doctoral dissertation, Universitas Negeri Malang).

[3] Sawitri, D. W. (2014). Pengembangan Modul Keanekaragaman Hayati Berbasis Pendekatan Saintifik Untuk Siswa Kelas X SMA. Berkala Ilmiah Pendidikan Biologi (BioEdu), 3(3).
[4] Zuhra, F., Hasan, M., \& Safitri, R. (2017). Model pembelajaran learning cycle $7 \mathrm{e}$ berbantuan buku saku terhadap hasil belajar siswa SMA. Jurnal Pendidikan Sains Indonesia (Indonesian Journal of Science Education), 5(1), 134-139.

[5] Fatimah, S., Sarwanto, S., \& Aminah, N. S. (2013). Pembelajaran Fisika Dengan Pendekatan Problem Based Learning (PBL) Menggunakan Modul Dan Buletin Ditinjau Dari Kemampuan Verbal Dan Motivasi Berprestasi Siswa. Inkuiri, 2(01).

[6] Hamdani. (2011). Strategi Belajar Mengajar. Bandung: CV Pustaka Setia.

[7] Indira, C. (2014). Best-Practices Pendekatan saintifik pada pembelajaran kimia di SMA Negeri 4 Sampit. Jurnal Kaunia, 10(2), 141151.

[8] Nasution, S. (2013). Berbagai Pendekatan dalam Proses Belajar dan Mengajar. Jakarta: PT Bumi Aksara.

[9] Sardiman A.M., (2011). Interaksi \& Motivasi Belajar Mengajar. Jakarta: PT Raja Grafindo Persada.

[10] Septianu, E., Sudarmin, S., \& Widiyatmoko, A. (2014). Pengembangan Modul IPA Terpadu Tema Perubahan Zat Berbasis Discovery Untuk Meningkatkan Keterampilan Generik dan Hasil Belajar Siswa. Unnes Science Education Journal, 3(3).

[11] Surachman, M., Muntari, M., \& Savalas, L. R. T. (2014). Pengembangan Multimedia Interaktif Berbasis Kontekstual untuk Meningkatkan Penguasaan Konsep dan Keterampilan Berpikir Kritis Siswa Kelas XI Pada Materi Pokok Sistem Koloid. Jurnal Pijar MIPA, 9(2).

[12] Suryaningsih, S., Muhlis, M., \& Jamaluddin, J. (2017). Efektivitas Penggunaan Modul Kerang Mutiara Berbasis Pendekatan Saintifik Terhadap Hasil Belajar Siswa Pada Mata Pelajaran Budidaya Di SMKN 1 Lembar. Jurnal Pijar Mipa, 12(2), 60-63.

[13] Yuniyanti, E. D. (2012). Pembelajaran Kimia Menggunakan Inkuiri Terbimbing dengan Media Modul Dan E-Learning Ditinjau dari Kemampuan Pemahaman Membaca dan Kemampuan Berpikir Abstrak (Pembelajaran Kimia Pada Materi Pokok Kesetimbangan Kimia Kelas XI IPA Di SMA Negeri (Doctoral dissertation, UNS (Sebelas Maret University)).

[14] Ningsyih, S., Junaidi, E., \& Al Idrus, S. W. (2016). Pengaruh Pembelajaran Praktikum Berbasis Inkuiri Terbimbing Terhadap Kemampuan Berpikir Kritis Dan Hasil Belajar Kimia Siswa. Jurnal Pijar Mipa, 11(1). 